\title{
Research on the Music Education for the Whole People
}

\author{
He Chang \\ School of Music \\ Baicheng Normal University \\ Baicheng, China
}

\begin{abstract}
Music education for all is a popular music education method aimed at improving the music literacy of the whole nation. In contrast, European countries such as France and Austria are very specific in this regard. Music is regarded as a basic education subject and cultivated from an early age. Starting with the current situation and future development strategies of music education in China, this paper comprehensively analyses the means and methods of popularization of music education, and at the same time explores the implementation strategy of implementing music education for all in China.
\end{abstract}

Keywords-music education for the whole people; literacy; diversity

\section{INTRODUCTION}

In the third session of the 12th National People's Congress, Premier Li Keqiang put forward that "I hope that the reading of the whole people can form an atmosphere everywhere." The reading of the whole people was once again written into the government work report, which called on the people to improve their cultural literacy through strengthening their reading and learning. As a teacher of music education, I realized that it was also necessary to carry out good music literacy education in the whole people under the call of premier Li.

\section{The PURPOSE OF PROJECT IMPLEMENTATION}

At present, folk music education in China mainly focuses on instrumental music education, ranging from children to old age. Learning music is mainly instrumental music, and piano performance is the main direction. However, from the longterm practice, only a few people have developed on the road of professional music, and most people have given up on the way to continuously learn music. This is mainly because the purpose of learning music initially is different. Although children music education is dominated by highly professional instrumental music, most parents want to cultivate their children's interest in music and master the skills. However, such monotonous and professional instrumental music education and practice has made people who are originally interested in music finally have an aversion to it. The reason for this is the result of the difference between the original learning purpose and the teaching direction. There are three main purposes for the implementation of music education for the whole people:

\section{A. Popular Music Education}

In order to correct the one-sided music education mode in the society, the popular music education mode is adopted to improve the students' music literacy, teach them in accordance with their aptitude, and teach music knowledge, harmony knowledge, music history, and various kinds of music knowledge in teaching. Improve and cultivate students 'interest in music in all aspects.

\section{B. Diversified Education Mode}

Through the implementation of this project, explore the correct direction of the healthy development of music for all. With the development of society, the problem of aging in China is relatively prominent. As of now, Chinese population over 60 years of age has exceeded 132 million, accounting for $10 \%$ of the total population of the country, and has entered the era of aging [1]. The quality of life of these elderly people is mainly reflected in two aspects - spiritual life and material life. Another purpose of this project is to train students to educate and help music lovers of all ages, so that all kinds of people have the opportunity to contact music, learn music, and enrich the spiritual life of the people.

\section{Standardizing the Development Direction of Social Music}

At present, the development of music in society has obvious utilitarianism. Many institutions and social networking websites transmit unhealthy music content. This problem affects the healthy development of music, but also transmits unhealthy ideas and affects the stable development of society [2].

\section{THE SIGNIFICANCE OF THE IMPLEMENTATION OF MUSIC EDUCATION FOR THE WHOLE PEOPLE}

\section{A. Improving the Music Literacy of the Whole People}

This project aims to improve students' interest in music literacy education, at the same time, enable students to master more professional knowledge, better serve the society, and provide more channels and directions for student employment. In the past, music education mainly focused on professional knowledge and skills. The cultivation of this kind of education 
mode is one-sided and unitary. It lacks universal education for all ages and classes. Through universal education, people of all kinds can learn music knowledge, which can improve their own literacy.

\section{B. Standardizing Music Education Program}

At present, higher music education training program in China is divided into two professional directions: music education and music performance. The direction of music performance is mainly to cultivate specialized talents engaged in music performance, singing and dance, and pays attention to professionalism and artistry. Music education is mainly to train professionals engaged in music teaching in primary and secondary schools. This direction is particularly important and plays a role in enlightening and guiding primary music education. So one of the significance of this project is to reform and standardize the training program of higher music education by means of theoretical research and field research, which is the core and fundamental starting point of improving the music quality of the whole people.

\section{Promoting the Construction of Music Culture for the Whole People}

The development of music in China can be divided into three main types [3]: classical music, folk music and popular music. Generally speaking, the trend of development tends to be popular and lacks the understanding and inheritance of classical music. In the process of pursuing individuality development blindly, popular music gradually breaks away from the pleasant role of music itself. Some music social software in network media even disseminates obscene content, and no longer has a good ideological orientation. Therefore, there is an urgent need for our country to guide and standardize the direction of music development through certain methods and means in order to return to the track of normal development.

\section{Expanding Employment Channels}

Through the implementation of music education for all programs, it is possible to attract more music lovers in society to learn music and inherit music. Therefore, more music teachers are needed to expand the employment path of students, and it is also conducive to the healthy and orderly development of society [4].

\section{CONTENT OF Music EducAtion For THE Whole PEOPLE}

The content of music education for the whole people is mainly analyzed and researched from three directions:

\section{A. Research on the Content of Music Education for the Whole People}

Investigate the research of all levels of society, explore the direction of music education for the whole people, write a plan, and propose practical methods and specific implementation steps.

\section{B. Research on Methods and Ways of Music Education for the Whole People}

Collect materials and information, understand the degree of social demand for various types of music, study the combination of local college music professional education and music literacy education to cultivate students' practical ability; Research and develop ways and means of music education for the whole people.

\section{Research on the Construction of Quality Culture of Music for the Whole People}

The music education of the whole people is in the contemporary era, and it is beneficial to the future. Through the project research, the program of music literacy education for all social strata is formulated, so that all strata and all ages can accept the training of music literacy and standardize the development direction of social music culture.

\section{BASIC CONDITIONS FOR RESEARCH AND IMPLEMENTATION OF MUSIC EDUCATION FOR THE WHOLE PEOPLE}

\section{A. The Teacher Conditions for Music Education of the Whole People}

On the basis of existing professional knowledge, music teachers in colleges and universities should constantly improve their professional knowledge through online learning and refresher learning, keep abreast of the latest educational and teaching contents, grasp the market needs, and give guidance and help to students.

\section{B. The Facilities and Conditions for Music Education of the Whole People}

The college music school is used as an education base to provide students with convenient conditions such as venues, books, and musical instruments.

\section{IMPLEMENTATION PLAN}

\section{A. Forming a Team of Instructors}

Among the teachers of the Conservatory of Music, select teachers with high academic qualifications as the team of instructors.

\section{B. Social Market Research}

- To investigate the status, social needs and existing problems of music groups of all ages in cities and surrounding areas of the province;

- Investigate the types and quantities of music training institutions in the cities and surrounding areas in the province, the scale, structure, and basic conditions of survival and development of employees.

- Analyzing the relevant data of the survey, making indepth study on the existing problems of music education in the society, putting forward the problems, and combining with the data for research. 
C. Research on the Countermeasures for Music Education of the Whole People

Combined with the previous market research and theoretical research, this paper summarizes the direction of reform, draws up feasible music education training programs in colleges and universities, reform methods, social education methods and approaches for music education for the whole people, and standardized and supervised the development of social music markets.

\section{The Pilot Operation forMusic Education of the Whole People}

According to the reform plan, a music education and training institution for all people in the society will be established to provide music education to people of all ages in all walks of life.

\section{E. The Music Education Programme of the Whole People}

After investigation, trial operation, re-investigation, and mid-term rectification, a complete plan for the cultivation of music education for the whole people was finally formulated to enable the sound development of music education for the whole people.

\section{CONCLUSION}

Music education for the whole people is one of the important means to improve the artistic quality of Chinese national art. It is in the contemporary era, and beneficial to the future, we must pay attention to the educational role of music on the quality of the nation, promote the development of music universal education, and inherit the excellent cultural heritage of China. At the same time, we will create more excellent national spirit food and promote the prosperity and development of the nation.

\section{REFERENCES}

[1] Li Baoren, Research on Fiscal Policy in the Context of Chinese Population Ageing, Economic Science Press, 2017.08. (in Chinese)

[2] Zhang Xiaowu, The Development of Social Music Education Institutions and Auxiliary Systems Since the Reform and Opening Up and Their Role in Popularizing Music Education, Journal of Inner Mongolia Normal University, 2018.21. (in Chinese)

[3] Li Jiti, Analysis of Music and Works, Central University for Nationalities Press, 2003.04. (in Chinese)

[4] Zeng Suijin, Music Sociology Course, China Communication University Press 2010.01. (in Chinese) 